УДК 37.013 .42

DOI:

Юлія Грач, кандидат педагогічних наук,

доиент кафедри соиіальної роботи і соиіальної педагогіки

Хмельницького національного університету

\title{
СОЦІОКУЛЬТУРНА АНІМАЦІЯ У КОНТЕКСТІ СОЦАЛЬНО-ПЕДАГОГІЧНОЇ ДІЯЛЬНОСТІ ЗІ СТАРШОКЛАСНИКАМИ
}

Соціокультурна анімачія у процесі здійснення сочіально-педагогічної діяльності у сучасному суспільстві є надзвичайно актуальною, виходячи з розуміння як позитивних, так і руйнівних впливів оточення, у якому зростає дитина. Процес виховання та сочіалізації дитини відбувається безпосередньо та опосередковано через призму впливів різних соціальних обставин та сочіально-психологічних умов середовища. Необхідною передумовою вивчення сочуільно-культурної анімації в умовах здійснення сочіально-педагогічної діяльності є з'ясування суті, особливостей і механізмів розвитку та соціалізації старшого школяра.

Ключові слова: соціалізація; соціальний розвиток; соціокультурна анімація; соціальна ситуація розвитку; соціально-педагогічна діяльність.

Jim. 5.

Yuliya Hrach, Ph.D.(Pedagogy), Associate Professor of the Social Work and Social Pedagogy Department Khmelnytskiy National University

\section{SOCIO-CULTURALANIMATION IN THE CONTEXT OF SOCIO- PEDAGOGICALACTIVITY WITH SENIOR STUDENTS}

The author analyzes the problem of child's development and behavior in modern society, specifies the positive and destructive effects of the environment in which the child develops. In the article, the author focuses on child socialization, which passes directly and indirectly through the prism of the influences of various social circumstances and socio-psychological conditions of the environment. The author studies socio-cultural animation and defines this activity as a promising innovative direction of socio-pedagogical activities in the context of the organization of productive leisure of children and youth. In the article, the author defines that the socializing mechanism in the process of socio-cultural animation work is the coordinated interaction of all socio-educational institutions of modern society in order to socialize the child and meet its social needs. The author specifies the social needs of the modern child as a conditional platform on which social skills, knowledge, and abilities are built, and the degree of satisfaction/dissatisfaction of social needs is determined by social opportunities, the activity of the child in sociocultural activities. In the article, the author notes that in the socio-pedagogical context, meeting child social needs in the process of socio-cultural animation involves creating a specially organized socio-educational environment and targeted influence to ensure the optimal conditions for knowledge and understanding of socio-economic and environmental phenomena, cultural and spiritual heritage of mankind, the formation of socially significant values, assimilation and implementation of the activity-behavioral mechanism. The author focuses on the semantic constant of socio-cultural animation, analyzes the conclusions of scientists on the understanding of the definition of "joint action" in the context of socio-pedagogical activities. The author substantiates the process of socialization of the child during socio-cultural animation as one that is determined by the set of socio-educational influences of the environment on the one hand and the individual's ability to shield social reality on the other hand.

Keywords: socialization; social development; sociocultural animation; social situation of development; social and pedagogical activity.

П остановка й обгрунтування актуальності проблеми. Соціальний розвиток сучасної дитини старшого шкільного віку зумовлений динамічністю та мобільністю середовища, у якому дитина росте, розвивається та, відповідно, соціалізується. Зміни цінностей, вимог та ризиків сучасного соціуму постають причиною змін у соціальному баченні дитиною свого місця у сучасному світі. Це, відповідно, зумовлює та визначає рівень виникнення ризиків у поведінкових реакціях дітей та підлітків.
Аналіз основних досліджень і публікацій. Питання розвитку та соціалізації дитини знайшли досить широке відображення у дослідженнях як українських (Н. Побірченко, О. Кузьменко, Ю. Возна, Л. Люта, Л. Кизименко), так і зарубіжних (І. Ніколаєва, В. Бочарова, К. Роджерс, та ін.) дослідників.

Теоретико-практичному аналізу проблем неформальної освіти дитини присвячені праці українських (О. Безпалько, А. Капської, Л. Міщик), а також зарубіжних дослідників (М. Гурьянової, Ф. Зайбель, Б. Мандея). 


\section{СОЦІОКУЛЬТУРНА АНІМАЦІЯ У КОНТЕКСТІ СОЦІАЛЬНО-ПЕДАГОГІЧНОЇ ДІЯЛЬНОСТІ ЗІСТАРШОКЛАСНИКАМИ}

Метою статті $\epsilon$ теоретичне обгрунтування особливостей соціокультурної анімації у процесі здійсненні соціально-педагогічної діяльності зі старшими школярами.

Виклад основного матеріалу. Соціальне життя сучасного суспільства характеризується динамічністю, неузгодженістю пріоритетів та цінностей, зміною уявлень про важелі соціального виховання. Це пояснюється нестабільністю соціальної, соціально-політичної, економічної, екологічної та культурної сфер сучасного суспільства. За таких соціальних реалій викликом сьогодення постає вивчення й аналіз особливостей розвитку сучасної дитини в процесі соціокультурної організації простору навчання і виховання.

Проблема розвитку та поведінки дитини у сучасному суспільстві $€$ надзвичайно актуальною, виходячи 3 розуміння як позитивних, так i руйнівних впливів оточення, у якому вона зростає. Процес виховання та соціалізації дитини відбувається безпосередньо та опосередковано через призму впливів різних соціальних обставин та соціально-психологічних умов середовища.

Соціокультурна анімація визначається нами як перспективний інноваційний напрям соціальнопедагогічної діяльності у контексті організації продуктивного дозвілля дітей та юнацтва.

При цьому відзначимо, що соціалізуючим механізмом у процесі соціально культурної анімаційної роботи виступає злагоджена взаємодія усіх соціально-виховних інститутів сучасного суспільства з метою соціалізації дитини та задоволення іiї соціальних потреб.

Соціальні потреби сучасної дитини у контексті нашого дослідження ми розуміємо як умовну платформу, на якій вибудовуються соціальні навички, знання та вміння, а ступінь задоволення/ незадоволення соціальних потреб визначається соціальними можливостями, активністю дитини у процесі здійснення соціокультурної діяльності.

Також варто відзначити, що у соціальнопедагогічному контексті задоволення соціальних потреб дитини у процесі здійснення соціокультурної анімації передбачає створення спеціально організованого соціально-виховного середовища й цілеспрямованого впливу з метою забезпечення оптимальних умов для пізнання й осмислення дитиною соціально-економічноекологічних явищ, культурних і духовних надбань людства, формування соціально значимих цінностей, засвоєння та реалізації діяльнісноповедінкового механізму.

Для нашого дослідження цінним є розуміння поняття “розвитку” як процесу становлення особистості під впливом зовнішніх (соціальне оточення, сім'я, група ровесників, дозвілля тощо), так і внутрішніх (керованих та некерованих) чинників, визначальним серед яких - соціальне виховання [1]. Розвиток ми розуміємо як якісні зміни психіки дитини, набуття нею нових ознак сприйняття, уявлення, мислення, емоційновольової сфери, пам'яті, рис характеру тощо.

До загальних закономірностей розвитку дитини належать: єдність біологічного і соціального; взаємозв'язок діалектичного і сенситивного; єдність безперервності й перервності; залежність розвитку від задоволення потреб; його обумовленість специфікою соціального середовища, в тому числі зоною найближчого розвитку; активність у діяльнісній сфері.

Соціальна ситуація розвитку розуміється нами як вибірковий синтез безлічі реальних i потенційних соціально-виховних обставин, інтегрованих переживаннями сенсу життя у певному віковому періоді.

Уважаємо за доцільне акцентувати увагу на змістовій константі соціально-культурної анімації. При цьому проаналізуємо висновки науковців щодо осмислення дефініції “спільної дії” у контексті соціально-педагогічної діяльності.

У працях науковців, які розробляють проблематику “спільної”, “продуктивної дії”, “авторської дії”, “виклику”, розкривається пробна активність, яка перетворює соціальну ситуацію, та непередбачувана активність за результатом дитини. Виокремлюються "переживання" в структурі дії. Підкреслюється роль інших людей, “екрануються” інтенції дитини, що дає їй змогу “проявити себе" і усвідомити самозміну особистості.

Розглядаючи “спільну дію” як форму відносин “дитина - суспільство” Б. Ельконін, виділяе три форми ㄲï реальності дії: 1) відтворення і утримування ідеальної форми за допомогою іï моделювання; 2) звернення, тобто уявлення i жест. “Звернення передбачає становлення середовища, "соціальної ситуації, але не діючої особи”; 3) суб’єктивації просування - осмислена та усвідомлена самозміна [2, 39-41].

Відповідно до цих форм реальності Б. Ельконін ставить у відповідність форми спільної дії як соціокультурні феномени: досягнення (технологічний ланцюжок), відповідність (ритуальна організованість) і звернення (спроба співвіднесення мотиву і мети, яка виконується як ініціація, виклик, збудження потреби ) [2, 43]. Індивідуальна форма сукупної дії-це продуктивна дія. "Продуктом” у цьому випадку є “виклик, що 


\section{СОЦІОКУЛЬТУРНА АНІМАЦІЯ У КОНТЕКСТІ СОЦІАЛЬНО-ПЕДАГОГІЧНОЇ ДІЯЛЬНОСТІ ЗІСТАРШОКЛАСНИКАМИ}

обумовлює культурне зрушення, зміна соціальної ситуації”. Б. Ельконін зупиняється на проблемі переживання у структурі дії. Переживання розглядається ним як утримування відчуття себе. Суб'єктивація просування - це самовідчуття. Самовідчуття виникає лише за умови винесення його зовні, тобто лише у вдалому екрануванні. “Істотно, - підкреслює Б. Ельконін, - що в експериментах самовідчуття виникає не в дії подолання зовнішніх перешкод, а в пробнопошуковій дії чуттєвого, тілесного “самовизначення” $[2,45]$.

Екранування передбачає відображення внутрішнього і його “повернення” самій дитині. “...В житті дитини основними екранами $є$ інші люди, але не просто “інші”, і не просто “люди”, а інші люди які екранують, які здійснюють складну пробно-пошукову дію відображення, посилення і повернення. Саме такі дії становлять сутність інтимно-особистісного спілкування, вони і $\epsilon$ будівельним риштуванням співбуття, співприсутності, співпереживання" $[2,45]$.

Центр продуктивності - екрановане - у своїй повній формі $\epsilon$ перетворенням інтимнопсихологічного феномена на соціальний. Соціальність продуктивного дії, за Б. Ельконіним, проявляється: а) у зміні соціальної ситуації дії; б) у зміні предметного змісту дії; в) у “затвердженні" дії, тобто в "подоланні соціальної порожнечі навколо дії”. “... Самі собою ідея і сенс - це зовсім не наявні “соціальні відносини”, але вони існують практично у вигляді становлення цих відносин, що виражаються в утвердженні/ запереченні, прийнятті/неприйнятті як актуальності, так і можливості дії” [2, 48].

Аналізуючи зазначене вище, можемо відзначити, що процес соціалізації дитини під час соціокультурної анімації визначається та зумовлюється сукупністю соціально-виховних впливів середовища $з$ одного боку та здатністю особистості до екранування соціальної дійсності з іншого.

При цьому відзначимо, що екранування соціальної дійсності зазвичай має характер набутих особистістю цінностей та норм, ії уявлень про сенс життя. При цьому міра соціальної значущості екранування визначається та зумовлюється дією соціально-виховних впливів середовища. Відтак уважаємо, що змістове наповнення соціокультурного середовища розвитку дитини має бути спрямоване на соціальність продуктивної дії зокрема та на соціалізацію взагалі. Тому соціокультурну анімаційну діяльність у цьому контексті ми відзначаємо як рушійний механізм зміни та самозміни соціального розвитку особистості.
Для нашого дослідження вважаємо за доречне конкретизувати змістове наповнення поняття “культурно-дозвіллєва діяльність".

Сучасні практики та теоретики у сфері соціальної роботи аналізують соціальнопедагогічну діяльність як одну зі сфер реалізації соціокультурної діяльності загалом, де проявляються культурно-духовні і матеріальні цінності сучасного соціуму [3, 19].

Дефініція “анімації” у сучасній науці та практиці соціально-педагогічної роботи розуміється різносторонньо, проте дослідники наголошують на інноваційності цієї технології, її спрямуванні на процес оптимізації міжгрупових та міжособистісних взаємовідносин, головними засобами поліпшення якого $\epsilon$ духовне спілкування, духовне просвітництво та духовне подвижництво [4]. Головними завданнями анімації у сфері дозвілля вченими одностайно визначається створення умов, спрямованих на розвиток (соціальний, духовний, фізичний) дитини, а також вияв і використання соціально-культурних технологій та методів, за допомогою яких можна сприяти подоланню негативних проявів та особистісному удосконаленню.

Особливою сферою діяльності, де ведуться наукові дослідження з проблем соціокультурної анімації, є соціальна педагогіка, яка розглядає зміст педагогічної анімації як сукупність педагогічно організованих взаємодій соціального педагога і вихованця в дозвіллєвій сфері, за допомогою яких задовольняються і розвиваються оздоровчо-відпочинкові, культурно-освітні, культурно-творчі потреби й інтереси, створюються умови для формування соціальної активності особи, здібної до перетворення навколишньої дійсності. Цей напрям дослідження пропонує такий підхід до визначення функцій педагогічної анімації:

- релаксація - відновлення витраченої енергії, психосоматичне розслаблення, відпочинок, емоційна розрядка;

- комунікація - спілкування і взаємодія;

- когнітивізація - відкриття нового;

- креативізація - творчий розвиток у дії, в русі.

Виходячи $з$ розуміння функцій анімаційної діяльності, у контексті нашого дослідження вважаємо за доцільне відзначити, що їх ефективність та реальна значущість для соціального розвитку та формування дитини зумовлюється координаційними й інтеграційними механізмами їх взаємодії. При цьому варто акцентувати увагу на змістовій константі та методичному забезпеченні анімаційної діяльності.

Методичне наповнення соціокультурної 


\section{СОЦІОКУЛЬТУРНА АНІМАЦІЯ У КОНТЕКСТІ СОЦІАЛЬНО-ПЕДАГОГІЧНОЇ ДІЯЛЬНОСТІ ЗІСТАРШОКЛАСНИКАМИ}

діяльності визначається віковими, психологічними, соціальними чинниками середовища зазначеного виду діяльності. Зміст тренінгів, розвиткових вправ, занять, ігор тощо має бути спрямованим на соціальний розвиток дитини та реалізувати основні завдання соціалізації особистості.

Реалізацію зазначених методичних аспектів пропонуємо забезпечити використанням у практичній соціальній роботі таких методів: соціального навчання; соціального виховання; включення у соціально значущі відносини; проблем особистості; формування свідомості; загальні методи соціальної роботи: соціальної діагностики, соціальної профілактики, соціального супроводу; методи самовиховання тощо.

Ефективне впровадження зазначених методів пропонуємо поєднувати із використанням у практичній соціальній роботі з дітьми таких форм:

- включення дітей і дорослих у соціальну діяльність, соціально значущі справи, заходи;

- включення дітей і дорослих у соціально значущі відносини, в міжособистісне спілкування;

- встановлення взаємодії з іншими різними соціальними інститутами, окремими фахівцями, науковцями, практиками;

- наставництво з передачі соціального досвіду, соціальних потреб дітям і дорослим;

- соціальне навчання з розвитку, вдосконалення соціальних здібностей дітей і дорослих.

Таким чином, ефективність здійснення соціальної роботи 3 дітьми в процесі соціокультурної діяльності загалом залежить від успішної координації зусиль усіх соціальновиховних інститутів та активізації соціально спрямованої дозвіллєвої діяльності дітей.

Підкреслюючи творчу природу аніматорської діяльності і необхідність формування нових професійних якостей соціального педагогааніматора, дослідники акцентують свою увагу на його "харизматичних" якостях і здібностях, а саме: можливості впливати на вихованців, надихати, активізувати їх участь у процесі спілкуванні тощо [2].

У контексті нашого дослідження доречним $\epsilon$ акцентування уваги на ефективності впровадження соціокультурної анімації за умови здійснення соціально-педагогічної діяльності. Тому вважаємо за доцільне конкретизувати зміст поняття “соціально-педагогічна діяльність”, що є складним і багатогранним процесом організації соціальновиховної та соціально-культурної діяльності фахівців соціальної сфери.

Тому саме в особистісно-середовищному контексті соціально-культурна діяльність $є$ потужним механізмом реалізації неформальної освіти до дітей старшої школи.

Крізь призму розуміння сутності соціальнопедагогічної діяльності вважаємо за доцільне конкретизувати особливості соціального інституту.

Соціальні інститути керують поведінкою дитини через систему заохочень і санкцій, визначених нормами.

Для нашого дослідження важливим є аналіз особливостей соціальних інститутів, здійснений В. Торохтієм. Дослідник визначає такі риси соціального інституту: він існує як набір соціальних норм і приписів, які визначають правильні (необхідні суспільством) типи поведінки; він тісно пов'язаний з ідеологією і ціннісною системою суспільства; інституційні типи дій контролюються суспільством, а сам інститут контролює поведінку індивідів; соціальний інститут володіє необхідними матеріальними засобами і ресурсами $[5,7]$.

Соціальні інститути, як і кожне з утворень соціуму, володіють різними ресурсами і можливостями. У контексті здійснення соціокультурної діяльності дитини підліткового віку визначаємо пріоритетним соціально-педагогічний потенціал як ресурс соціально-культурної сфери соціальних інститутів, який певною мірою бере участь у соціалізації дітей, тим самим активізуючи задоволення соціальних потреб та виконуючи цим попередньо зазначене завдання нашого дослідження.

Висновки. На основі аналізу ідей, поглядів українських і зарубіжних теоретиків та практиків соціальної роботи та соціальної педагогіки, які слугують методологічним підгрунтям процесу соціокультурної анімації у контексті соціальнопедагогічної діяльності зі старшокласниками, 3'ясовано, що ефективність та гармонійність процесу соціалізації дитини залежить від належного рівня організації соціокультурної діяльності, від конструктивної співпраці в особистісно-середовищному контексті соціального розвитку старшого школяра.

Рекомендації. У сучасних умовах реформації соціальної роботи та соціальної педагогіки вважаємо за доцільне акцентувати увагу на організації соціально-культурної діяльності та створенні умов для повноцінної соціалізації дитини. Рекомендуємо активізувати якісно нові соціально значимі механізми впливу на процес соціалізації дитини, впровадити інноваційні моделі якісних формувально-розвивальних технологій у процесі розвитку та виховання сучасної дитини.

Перспективи подальших досліджень. Напрями подальших досліджень окресленої 
проблеми полягають у розробці соціальноорієнтованих інноваційних форм та методів соціокультурної організації соціально-виховного процесу, соціально-орієнтованої, анімаційної організації дозвілля та мотиваційному заохоченні старшокласників до продуктивного дозвілля.

\section{ЛІТЕРАТУРА}

1. Возна Ю. В. Соціалізація учнівської молоді в процесі функціонування соціально-педагогічного комплексу: дис... кандидата пед. наук. Київ, 2012. $276 \mathrm{c}$.

2. Ельконин Д. Б. Проблемы возрастной и педагогической психологи: избранные психологические труды / подред. Д. И. Фельдштейн. Москва, 1995. 224 с.

3. Киселева Т. Г., Красильников Ю. Д. Социально-культурная деятельность: учебник. Москва, 2004. 539 с.

4. Тарасов Л. В. Организация анимационного процесса в учреждении культуры с целью преодоления отчуждения молодых инвалидов от общества. Наука о культуре: современный статус. Сборник текстов докладов мељсвузовской научно-практической конференичии молодых учених / Под. ред. Жарковой Л. С., Черниченко В. И. Ч. 1. Москва, 2003. 212 с.

5. Торохтий В. С. Психология социальнопедагогической деятельности. Москва, 2010. $376 \mathrm{c}$.

\section{REFERENCES}

1. Vozna, Yu.V. (2012). Sotsializatsiia uchnivskoi molodi $\mathrm{v}$ protsesi funktsionuvannia sotsialnopedahohichnoho kompleksu [Socialization of student youth in the process of functioning of social and pedagogical complex]. Candidate's thesis. Kyiv, 276 p. [in Ukrainian].

2. Elkonyn, D. B. (1995). Problemy vozrastnoy i pedagogicheskoy psikhologi: izbrannye psikhologicheskie trudy [Problems of developmental and educational psychology: selected psychological works]. Moscow, 224 p. [in Russian].

3. Kyseleva, T. H. \& Krasylnykov, Yu. D. (2004). Sotsialno-kulturnaya deyatelnost: uchebnik. [Sociocultural activities]. Moscow,539 p. [in Russian].

4. Tarasov, L. V. (2003). Organizatsiya animatsionnogo protsessa v uchrezhdenii kultury s tselyu preodoleniya otchuzhdeniya molodykh invalidov ot obshchestva [Organization of the animation process in a cultural institution in order to overcome the alienation of young disabled people from society]. Cultural Science: Current Status. Collection of reports of the interuniversity scientific-practical conference of young students. (Ed.). Zharkova L. S., Chernichenko V. I. Part 1. Moscow, 212 p. [in Russian].

5. Torokhtyi, V. S. (2010). Psikhologiya sotsialnopedagogicheskoy deyatelnosti [Psychology of social and educational activities]. Moscow, 376 p. [in Russian].

Стаття надійшла до редакції 12.10.2020

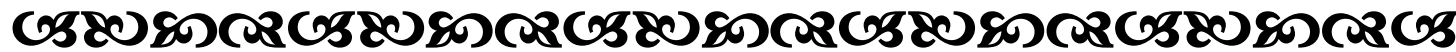

"Людина - вища цінність, єдиний творець усіх досягнень қультури на Землі, розумний центр Всесвіту, той пункт, від якого все повинно починатися $i$ до якого все повинно повертатися".

Dені Diдpo
франчузький білосоø

“ТІреба вчити не думкам, а мірқувати”.

Іммануї Кант німецький білософб

“Наші знання - ие сума того, чого ми навчилися, й того, що ми забули”.

Марія бон Ебнер-Ешенбах баронеса, австрійсьқа письменниия

“Дюдина залишає себе насамперед у людині. У иъому наше безсмертя. У иъому найвище щастя і сенс життя.. .

Василь Сухомлинський український педагог, публіиист, письменник, поет

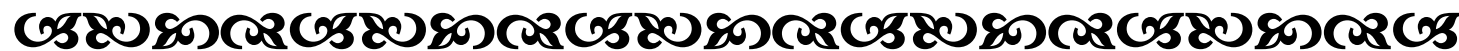

Молодь і ринок №6-7 (185-186), 2020 